\title{
FOREIGNERS'ACQUISITION OF IMMOVABLE PROPERTY IN THE FRAMEWORK OF LEGAL BASIS, SOCIOLOGICAL RISKS AND SUGGESTIONS
}

\author{
Ayhan Dolunay ${ }^{1}$ \\ Fevzi Kasap ${ }^{2}$
}

\begin{abstract}
Persons are not subject to citizenship or, in other words, states that they consider to be foreigners are subject to the rules / restrictions imposed on them by the state concerned if they wish to acquire immovable property in the territory of their sovereignty and where immovable acquisition of foreigners is possible in the country of the immovable. In our work, the issue of foreigners' acquisition of foreigners in the North Cyprus, which is regarded as a national issue in terms of the Turkish world. The concepts of "foreign" and "immovable" shall be defined first and then by considering the rules / limitations on the immovable acquisition of foreigners in the North Cyprus, the method of acquisition in accordance with law and the method of acquisition which is frequently applied and the territories of the North Cyprus. Far beyond, the
\end{abstract}

Turkish Cypriot people; we will propose solutions to overcome this serious issue and the other negativities that have been identified by evaluating the acquisition method by cheating against the blood which may lead to "assimilation" of the Turkish people in the island.

Keywords Acquisition of Immovable Property, Foreigners, North Cyprus.

\section{INTRODUCTION}

Although the acquisition of immovable properties is a matter of having a procedure that varies from country to country; The issue of noncitizens of the relevant country, in other words the "foreigners", the acquisition of immovable property, usually carries relatively difficult conditions for the acquisition of citizens. On the other hand, when there is an element of

\footnotetext{
${ }^{1}$ Near East University, Vice Director of Graduate School of Social Sciences, Faculty of Communication, Member of Communication Research Center, Nicosia, North Cyprus, Mersin 10 Turkey. ayhan.dolunay@neu.edu.tr https://orcid.org/0000-0003-1862-4500

${ }^{2}$ Near East University, Faculty of Communication, Head of Radio, TV and Cinema Department and Communication. Research Center, Nicosia, North Cyprus, Mersin 10 Turkey. fevzi.kasap@neu.edu.tr https://orcid.org/0000-0003-3965-3837
} 
foreignness in terms of person's origin; in other words, the ones who will acquire immovable property in this regard are foreigners; the relevant arrangements must be made with great precision. Because, although the issue is the subject of international private law, excessive lyre regulations may provoke a backlash in the international arena against the country concerned. Quite so, the failure to make legal arrangements with precision can lead to issues not only in terms of international relations, but also to immovable property acquisitions with unfair means, and sociological problems in this context. The immovable property acquisition of citizens in North Cyprus is regulated by the Immovable Property Act (Chapter 224); The acquisition of foreigners is regulated by the Real Estate Acquisition and Long-Term Rental (Foreigners) Act no. 52/2008 and the Long-Term Real Estate Leasing (Foreigners) Regulation no. 262/2016. Although North Cyprus is an unrecognized (See Aust, 2005: 26; Crozat, 1953: 15-16; Meray, 1959: 214) country in terms of international law (Dolunay \& Kasap, 2020), considering the number of foreigners living in the country, the above specified relevant arrangements outlined in a very precise manner; in addition, the example of our approach to the point of being able to cause sociological problems is directly contained in the law are the reasons this article has been prepared and includes recommendations for revising relevant legal regulations.

\section{AIM, SCOPE AND METHOD}

This study focuses on the procedure for foreigners (non-citizens of the relevant country) to acquire immovable property in the country. In this context, the acquisition of immovable properties of foreigners to be addressed is limited to North Cyprus

The study possesses the nature of an interdisciplinary study that includes law (States Private Law) due to foreigners being the subject of the study, international relations due to the consequences of foreigners being the subject and sociology due to possible adverse outcomes of these regulations.

In the study, the concepts of foreigner and immovable property will be defined primarily within the framework of literature screening. Then, the law and regulation on the acquisition of immovable property in North Cyprus will be examined. And the basic principles of the acquisition of immovable property for the foreigners in North Cyprus according to the law and 
GÊNERO E

INTERDISCIPLINARIDADE

the regulation will be analyzed.

In this context, in the research section of the study, within the scope of document analysis from qualitative research methods, in the form of law analysis, the relevant laws and regulations will be subject to examination.

It was useful to define that document moaning is the analysis of the written materials related to the phenomenon or cases targeted to be investigated (Yıldırım \& Şimşek, 2006 This technique, calls "documentary observation" by Duverger (1973). Best (1959: 118) refers to the technique as "systematic examination of existing records or documents as a data source". Document analysis can be a basic data collection tool, as it is impossible to have direct interviews and observations, or it can be preferred to associate the data obtained with interviews and observations.

The data obtained were analyzed by content/law analysis technique. Content analysis is a research technique in which valid comments extracted from the text are revealed as a result of successive processes (Weber: 1989: 5; Koçak \& Arun, 2006: 22).

\section{DEFINITIONS}

Vol no $02 \mid n^{0} 01$ | ISSN: 2675-7451

https://www.periodicojs.com.br/index.php/gei/index

\subsection{Foreigner}

The generally accepted definition of the concept of "foreigner" is the definition that was adopted at the 1892 Geneva Convention. According to the document, "Foreigner; a person who is in the country and does not have the right to claim the nationality of that state."

In the definition given, the phrases " not have the right to claim the nationality" and "is in the country" are the subject of criticism. That is to say, a person who is tied to a country with the bond of citizenship, has that bond without the necessity of having the right to claim it. On the other hand, it is not possible to limit "foreigners" to those in the country at the time. In such a way that, people who were not in the country at the time but were not affiliated with that country with citizenship ties are also foreigner to the country (Aybay, 2010: 13).

Following the general approach and criticism of this approach, which we have acknowledged as well, it is worth examining the Turkish Cypriot law regulations on our study's subject in terms of definition.

The definition of the concept of "foreigner" is included in article 52/2008, "Law on Acquiring Immovable 
Property and Long-Term Rental

(Foreigners)" and article 2 of the relevant arrangement is as follows:

"Foreigner" describes the real person who is not a citizen of the

Turkish Republic of Northern

Cyprus and also includes foreign legal entities.

Regarding the concept of "Foreigner", the Regulation under Article 4(1) of the Law No. 155 of Acquiring Immovable Property and Long-Term Rental (Foreigners) (Law No. 52/2008), and the regulation of Interpretation under the law, Article 2, mentions the following provision:

"Foreigner" describes the meaning given to it in the Acquiring Immovable Property and Long-Term Rental Act.

In this context, the definition of foreigner is common in the legal arrangements related to subject of our study and is expressed as a natural or legal entity who is not a citizen of North Cyprus ${ }^{3}$.

As it turns out, the statements "not to be in the country" and "not having

\footnotetext{
${ }^{3}$ People to be accepted as foreigners in general are classified as; "Citizens of a foreign state", "stateless" and "refugees" would be the
}

right to claim the nationality", which is the subject of criticism that we acknowledged in regarding the general definition, were not included in the relevant arrangement, and in our opinion, a correct adaptation was made.

\subsection{Immovable Property}

"Immovable" can be defined in general as "items that are not capable of moving from one place to another without damaging its essence" (Ertaş, 2011: 8).

Regarding the concept of "Immovable", " Acquiring Immovable Property and Long-Term Rental (Foreigners) Act No. 52/2008", Article 2 of the interpretation and No. 155 the Regulation under Article 4(1) of the Law on Acquiring Immovable Property and Long-Term Rental (Foreigners) Act No. 52/2008 states that:

"Immovable Property" describes the meaning given to it in the Immovable Property (Savings, Registration and Appreciation of Assets) Act.

In this context, when the relevant " Immovable Property (Savings,

appropriate way to go to a distinction in the form of (Mutlu, 2005: 265; Güven, 2011: 206). 
Registration and Asset Appreciation) Law" referred to both in law and Regulation observed, the article 2 with side title "Interpretation" states that the definition of "Immovable Property" is been under regulation. That statement is as follows:

"Immovable property":

(a) The land;

(b) Buildings connected to any land or building, or other construction or construction connected to buildings and other construction, construction or outbuildings;

(c) Trees, any other trees planted in vineyards and land, or growing on land, and their uncollected products;

(d) Rights in spring, well waters and waters, which are owned together with or separate from any land;

(e) Any land or any building or other construction or the connected to the building or default royalty, liberty, appurtenances right or any other kind of rights and interests; (f) undivided shares in any properties mentioned above are all included.

In this context, foreigners can obtain all of the ones specified in the regulation in North Cyprus as immovable property under certain conditions.

\section{Law of Foreigners} Acquisition of Immovable Property in NORTH CYPRUS

As included under the heading "Definitions", the acquisition of immovable properties in Turkish Cypriot Law is regulated under the "Law on Acquiring Immovable Property and Long-Term Rental (Foreigners) No. 52/2008".

On the other hand, the other regulation contained under the heading "definitions" is the "Regulation under Article 4(1) of the Law no. 155 of the "Acquire of Immovable Property And Long-Term Rental (Foreigners) Law No. $52 / 2008$ ", includes only one of the limitations on the acquisition of immovable property of foreigners, not the explanations for the implementation of the law.

Finally, the Regulation of Limitations on the acquisition of immovable property of foreigners no. 
$155 / 2012$, which has a title on the relevant issue, is not regulating the acquisition of immovable property of foreigners, but the rental of immovable property. Therefore, although there is a similarity to the name, it loses its direct interest in the issue.

\subsection{Acquisition of Immovable}

\section{Property and Long-Term Renting} (Foreigners)

In Turkish Cypriot Law, the issue of the acquisition of immovable property of foreigners is regulated by a separate law, different and more in place than the way it is regulated in Turkish Law. Given the importance of the issue, it will be supported in our opinion that it is more appropriate to make regulations with a separate law. ${ }^{4}$

Law no. $52 / 2008^{5}$, which includes a total of 16 articles, including provisional rules, consists of five key sections: "General Rules", "Basic Rules for Long-Term Rental", "Rules on Buying Immovable Properties", "Various Rules" and "Provisional and Final Rules".

Law no. 52/2008, "Right to

\footnotetext{
${ }^{4}$ In Turkish Law, the acquisition of immovable property is regulated not by a special regulation, but within the Land Registry Law no. 2644.

5 "The purpose of this Law is to use long-term lease or purchase methods. Turkish Republic of
}

Acquire Immovable Property of Foreigners" side titled article 5, states the following provision:

"Foreign real or legal persons within the borders of the Turkish Republic of Northern Cyprus;

(1) may acquire immovable property by long-term lease, if they adhere to the rules of articles 6,7 and 8 or;

(2) may purchase immovable property if they adhere to article 9 of this Law."

In this context, as stated, in the articles 6,7 and 8 of the law regulate the leasing of the immovable property, however, article 9 regulates the purchasing of immovable property.

4.2. Regulation under the Acquisition of Immovable Property and Long-Term Renting (Foreigners) Law Art. 4(1)

Regulations are generally written rules of law issued to demonstrate the implementation of a law and to indicate the work it orders (Gözler, 2011: 41). In this context, it may

Northern Cyprus it regulates the rules that foreigners who wish to acquire immovable properties will be subject to." (52/2008 IPFL, "Purpose" side-titled art. 3). 
be considered that the Regulation no. 155 under Article 4(1) of the "Law No. $52 / 2008$ " of the "Acquisition of Immovable Property and Long-Term Rentals (Foreigners) Act" shall be issued in order to show the implementation of the Law on Immovable Property And Long-Term Rental (Foreigners) and to indicate the work it has ordered. However, let's reiterate that this is not the case here.

As a statement, law no 52/2008. In art. $4 / 1$, the following provision includes:

"The Council of Ministers, 'with a regulation to be published in the Official Gazette, may determine that foreigners cannot obtain ownership rights on any immovable property except that they are through succession within the regions to be determined in the regulation after the date of the regulation. Any record made in the relevant Land Registry and Cadaster Office in violation of such regulation rules is deemed invalid."

In accordance with the regulation, the Council of Ministers has been authorized to impose geographical restrictions on the acquisition of immovable property foreigners and it has been stated that this limitation can be made by regulation. In this context, Regulation no. 155 was issued by the Council of Ministers.

Regulation No. 155 consists of a total of 7 articles, including temporary and final rules, but not in terms of the disclosure of the regulations contained in Law no. 52/2008, but to prevent foreigners from obtaining immovable property from military restricted areas under the specified authority.

Regarding this arrangement, it would be appropriate to draw attention to the two points.

Firstly, it cannot be understood why an important issue such as not being able to acquire immovable in military prohibited areas is not regulated by law and regulated by regulations. In our opinion, it would be more appropriate to include the relevant restriction in the law without the need for a separate regulation.

On the other hand, "If the foreigners from the military prohibited areas were not forbidden to acquire immovable from the military prohibited areas with the charter issued in the light of the authority granted to the North Cyprus Council of Ministers, would it be possible for foreigners to obtain 
immovable from the military prohibited areas?" question comes to mind. It should be noted that it is not possible to obtain immovable from military forbidden areas anyway, even if the relevant restriction was not brought by a cabinet by the ministers, it would not be possible for foreigners to acquire immovable from these regions.

5. BASIC PRINCIPLES OF FOREIGNERS ACQUISITION OF IMMOVABLE PROPERTY IN NORTH CYPRUS

\subsection{Permission of Council of} Minister

Acquisition of Immovable Property and Long-Term Rental Foreigners- Law (IPFL) no. 52/2008, "Rules for Buying Immovable Property" side titled art. 9.

"Foreign real or legal persons can purchase immovable property within the Borders of the Turkish Republic of Northern Cyprus provided that the Council of Ministers has already been granted permission..."

In this context, the first requirement for foreigners to buy immovable property in North Cyprus is to obtain permission from the Council of
Ministers. It is not possible to obtain immovable property without the permission of the Council of Ministers for people who are not Turkish Cypriot citizens.

\subsection{Legal Restrictions}

\subsubsection{Limitations of Area}

Law no. 52/2008, the second sentence of art. 9 is as follows:

"... Article 8 of this Act also applies to purchasing rules."

In this context, the rules for the acquisition of immovable property in North Cyprus of foreigners, IPFL no. $52 / 2008$. With art. 9 , numbered 52/2008, which regulates the long-term real estate rental of foreigners in North Cyprus. It's connected to 8 .

In light of this citation, IPFL no. $52 / 2008$. When art. 8 is examined, the limitation of the area (art. 8/1) is first encountered. The relevant edit is as follows:

"If the immovable property to be rented is land, the area cannot be more than 1 acre (14400 square feet); if there is a residence or an apartment, the area of the land cannot be more than 5 acres."

In accordance with the 
GÊNERO E

INTERDISCIPLINARIDADE

regulation, the upper limit of land applied for land that foreigners will acquire in North Cyprus is an acre. As for foreigners to acquire houses or apartments in North Cyprus, the upper limit of land applied for the land on which the residence or apartment is located is five acres.

In case foreigners buy a house with a face area of more than an acre, demolish the residence and thus buy an acre of vacant land, they will still be able to obtain five acres of land. The following provision in 8/1 will apply:

"However, no other housing or apartment can be built on the land rented as a residence or apartment."

In this way, it was tried to prevent foreign people from demolishing the house they bought, obtaining empty land above the border and building another building here.

On the other hand, in relation to the acquisition of immovable property in North Cyprus by foreign investors, Regulation no. 52/2008 has an exception.

"Regardless of the (1st paragraph rules) of this article for investment longterm rentals, the Council of Ministers may allow long-
Vol no $02 \mid n^{\circ} 01$ | ISSN: 2675-7451

https://www.periodicojs.com.br/index.php/gei/index term leases. It is condition for the foreigner who will make long-term leases for investment purposes to deposit at least 3 (three) Million Euros into the name or account of himself or his company and use this amount for investment purposes. It revokes the permit given if the Council of Ministers determines that this amount is not used for investment purposes." (art. $8 / 3)$.

In this context, foreign investors, North Cyprus, if they invest at least three million Euros, with the permission of the Council of Ministers, they will be exempt from the abovementioned land limitation. However, if the Council of Ministers determines that the amount in question is not used for investment purposes, the right of exemption will be eliminated; property rights of the immovable properties they acquired will also be lost.

On the other hand, foreign investors, the limitations of the acquisition of immovable property in North Cyprus, without the amount in question, by applying to another method, they are seen to be exceeded: Foreign 
persons, Turkish Cypriot citizens by agreeing to establish a company, the company established $51 \%$ stake belongs to the relevant Turkish Cypriot citizen, and thus, the established company has the status of "domestic" company and subject to foreigners in North Cyprus without limitation, "unlimited" property gain.

In this context, with the sums transferred to the company in question by the foreign investor, the company can acquire immovable properties well above the immovable limit that foreigners can acquire (Mamal1, 2012, Feb 26). This situation must be prevented by a new clause to be added to the law or an overhaul of the existing article.

\subsubsection{Restrictions of Military}

\section{Forbidden Zone}

Law no. 52/2008, titled "Restrictions on the Acquisition of Immovable Property for Foreigners in Some Cases". As stated above, 4/1 has given the Council of Ministers the authority to issue restrictive regulations for the acquisition of foreigners for immovable property. With the Regulation No. 155 on the Restrictions on the Acquisition of Immovable Property for Foreigners, it was forbidden for foreigners to acquire immovable in military prohibited areas.

Related Regulation Art. 4 is as follows:

"In accordance with the Military Forbidden Zones Decree, foreigners cannot obtain immovable property in the 1 st Military Forbidden Zones and Military Security Regions."

At this point, it is useful to determine the scope of the expressions "1st Military Forbidden Zones" and "Military Safety Zones". When the Military Forbidden Zones Decree No. 5/1979, which has been cited, is examined, it is seen that the regions where foreigners cannot acquire immovable property are stated as follows:

"1st Military Forbidden Zone: Border (is the zone between the contact line and the hay formed by joining the points passed 500 meters behind the border (contact line)." (Art. $3 / a, 1)$.

"Military Safety Zone: Military Safety Zone is defined as the 1st Military Forbidden Zone and certain and individual locations marked with each type such as Military facility, Headquarters, explosive warehouse, fuel-gas warehouse and facilities, Role 
station and their outer edges. These are the regions or regions that are formed by joining the points up to 300 meters away and require special safety measures. These regions are indicated on the land with wire fences and warning signs." (art. 3/a, 4).

In this context, foreigners cannot acquire immovable property in the regions specified in the North Cyprus.

\subsubsection{Limitation on Foreign}

\section{Person's Special Status}

Law no. 52/2008, art. 4/2 contains the following provision:

"The Council of Ministers may restrict some foreign real or legal persons or foreign legal entities as directors, managers, shareholders or members to purchase immovable property or to make long-term leases, due to their special status."

In this context, the Council of Ministers takes into consideration the "special status" of the people who want to purchase immovable property in the North Cyprus and can reject the request to acquire the immovable in any situation that may appear to be "contrary".
Moreover, contrary to such a decision, any registration to be made by the land registry office is deemed to be regulated in the same article in which it will be deemed invalid.

Although it is not understood exactly what is targeted with the expression of "special status" of the person who wants to acquire immovable property, as stated, the authority of evaluation has been given to the "Council of Ministers" completely. Although this situation may be considered to be contrary to the principle of "legal security", it is also understandable that states observe their public priorities in foreign affairs, especially in foreigners' acquisition of property in their country. Although it is desired to make the statement "clearer" and thus to understand the scope, at this point, the authority of "sovereignty" was emphasized; It is aimed that the Council of Ministers has a wide discretion.

As an example of restriction on the basis of the special status of foreigners, for example, public officials and even citizens of country $\mathrm{X}$, which is at war with the North Cyprus, are not given the right to acquire immovable property in North Cyprus.

\subsubsection{Limitations about}


National Security and Public Order

Law No. 52/2008, art. 4/2 contains the following provision:

"The Council of Ministers may restrict some foreign real or legal persons or foreign legal entities from the director, manager, shareholder or members of the property to purchase real property or long-term lease ... because it is an immovable property that may endanger national security or public order."

In this context, the Council of Ministers can reject foreigners' requests to acquire immovable property in North Cyprus due to national security or public order. Just as with the "special status of foreigners", the authority is entirely "completely" in the Council of Ministers. Despite the fact that the scope of the statements in question could not be fully stated, although it may be thought that the authorization of the authority to the

\footnotetext{
${ }^{6}$ Public order attribute by as well as being a difficult concept to describe, there are several suggestions about definition, which vary according to time and place factors. According to a description, "In general, it can be said that in a given country, at a certain time, matters that concern public benefits and general morality regarding public conscience are in public order." (Ökcün, 1967: 14; Ruhi, 2013: 80; Full moon,
}

Council of Ministers also contradicts the principle of "legal security", let us reiterate that the states should observe their public priorities in the acquisition of immovable property in foreign countries, especially foreigners. is an understandable situation.

As an example of situations in which foreigners' requests to acquire immovable may be rejected on the grounds of "National Security", immovable properties at strategic points for North Cyprus can be cited. For example, in Karpaz Cape, which is considered strategically important, foreigners will be prevented with the high probability of acquiring immovable assets, and if the foreigners constantly demand to acquire immovable property in the coastal areas, a rejection decision can be made due to the general reason that the coasts will "shut down".

As an example of situations where foreigners' requests to acquire immovable property can be rejected on the grounds of "Public Order" this

2014: 47) According to another definition, "The rule of public order is legal rules that protect the basic structure and interests of a particular society organized at a certain time" (Hâtemi, 1976: 158; In summary, public order, taking care of the basic structure and interests of society, Wide it was a concept (Gökyayla, 2011: 26; Full moon, 2015: 93). 
situation may affect the Turkish Cypriot community through the immovable property that a foreigner wants to buy against the general moral structure of the Turkish Cypriot community, and İn case of rejection of the request, it can be shown.

\section{RESULTS AND}

\section{CONCLUSION}

Foreigners can obtain an immovable property in the Turkish Republic of Northern Cyprus, provided that the specified conditions are met. If we repeat briefly in titles, the relevant terms are as follows:

- Getting permission from the Council of Ministers,

- To comply with the area limitation,

- The immovable is not located in the military prohibited area

- The private status of the person is not seen to be inconsistent,

- No violation of national security and public order.

If these conditions are fulfilled, foreigners can obtain immovable property in North Cyprus.

On the other hand, our concrete solution suggestions are as follows in order to overcome a number of negative issues that we have determined regarding the acquisition of foreigners in the North Cyprus:

Firstly, as we have stated in our study, regulations are generally written rules of law that are issued to show the implementation of a law and to specify the jobs it orders. However, Regulation no. 155 is not about the explanations regarding Law No. 52/2008, but about foreigners acquiring immovable from military prohibited areas. In our opinion, it would be appropriate to arrange this issue in Law No 52/2008 instead of a separate regulation.

Another important issue is the unfair acquisition of foreigners by establishing a company together with real persons who are Turkish Cypriots, in order to obtain unlimited real estate, which we mentioned in our study; A new item should be added to Law no. 52/2008 or revision should be made in the current regulation and this situation should be prevented.

\section{References}

Aust, A. (2005). Handbook of International Law. Cambridge: Cambridge University Press. https://doi.org/10.1017/CBO978051149 
Aybay, R. (2010). Yabancilar Hukuku. İstanbul: Bilgi University Publishing.

Crozat, C. (1953). The International Law

in Recognition (Trans. Edip Çelik), İÜHFD, XIX(1-2), 3-32.

Dolunay, A. (2014). Yabancı Mahkeme Kararlarının Tanınması ve Tenfizinde Kamu Düzeni, Prof. Dr. Ylldırım Uler'e Armağan içinde, 45-63. Nicosia: Near East Publishing.

Dolunay, A. (2015). Türk Hukukunda ve Kıbrıs Türk Hukukunda Yabancı Mahkeme Kararlarının Tanınması ve Tenfizi. İstanbul: Oniki Levha.

Dolunay, A. \& Kasap, F. (2020). Still Unrecognized State "Turkish Republic of Northern Cyprus" in the Context of the Cyprus Negotiations: Status of the TRNC' Court Decisions, Journal of Politic and Law, 13(3), 1-9.

Duverger, M. (1973). Sosyal Bilimlere Giriş. (Trans. U. Oskay). Ankara: Bilgi Yayınevi.

Ertaş, Ş. (2011). Eşya Hukuku. İzmir: Seçkin.

Gökyayla, D. C. (2001). Yabancı

Mahkeme Kararlarının Tanınması ve Tenfizinde Kamu Düzeni. Ankara: Seçkin.

Gözler, K. (2011). Hukukun Temel Kavramları. Bursa: Ekin Publishing.

Güven, P. (2011). Anayasa Mahkemesi Kararları Işı̆̆ında Yabancı Uyruklu
Gerçek Kişilerin Türkiye'de Taşınmaz Ve Sınırlı Ayni Hak Edinmesinde Tapu Kanunu 35'inci Maddesinde Değiş̧iklik Öngören Kanun Tasarisının Değerlendirilmesi, Milletlerarası Hukuk ve Özel Hukuk Bülteni, 31(2), 204-300. Hâtemi, H. (1976). Hukuka ve Ahlaka Aykırılık Kavramı ve Sonuçları. İstanbul: İstanbul University Publishing.

Koçak, A \& Arun, Ö. (2006). İçerik Analizi Çalışmalarında Örneklem Sorunu, Selçuk Üniversitesi İletişim Fakültesi Dergisi, 3(4), 21-28.

Mamal1, B. (2012 Feb. 26). KKTC'de yabancıların herhangi bir gayrimenkul edinmesine kimsenin bir itirazı olamaz. Retrieved from: http://www.kibrispostasi.com/index.php /cat/35/news/72282

Meray, S. (1959). Devletler Hukukuna Giriş. Ankara: Ankara Üniversitesi Basımevi.

Mutlu, L. (2005). Yabancı Kişilerin Taşınmaz Mal Edinimi Yönünden Avrupa Birliği Ve Türkiye”, Türkiye Barolar Birliği Dergisi, 59, 264-309.

Ökçün, A. G. (1976). Devletler Hususî Hukukunun Kaynaklarl ve Kamu Düzeni. Ankara.

Ruhi, A. C. (2013). Türk Hukukunda Yabancı Boşanma İlamlarının Tanınması ve Tenfizi. Ankara: Seçkin.

Weber, R., P. (1989). Basic Content 
Analysis. London: Sage.

Yıldırım, A. \& Şimşek, H. (2008).

Qualitative Research Methods in Social

Sciences. Ankara: Seçkin 